\title{
Effects of Sentence Making, Composition Writing and Cloze Test Assignments on Vocabulary Learning of Pre-intermediate EFL Students
}

\author{
Zeinab Talebzadeh \\ Department of English Shiraz Branch, Islamic Azad University, Shiraz, Iran \\ 47, Kucheh 12, Khakshenasi Street, Shiraz, Iran \\ Tel: 98-711-227-0133 E-mail: zeinab.talebzadeh@yahoo.com \\ Mohammad Sadegh Bagheri (Corresponding author) \\ Department of English Shiraz Branch, Islamic Azad University, Shiraz, Iran \\ \& English Language Department, Pardis Campus, Islamic Azad University, Shiraz Branch, Shiraz, Iran \\ Tel: 98-91-7114-0529Ｅ-mail: Bagheries@gmail.com
}

Received: November 13, 2011

Accepted: December 4, $2011 \quad$ Published: February 1, 2012

doi:10.5539/ijel.v2n1p257

URL: http://dx.doi.org/10.5539/ijel.v2n1p257

\begin{abstract}
This study aimed to investigate the effects of three writing assignments (sentence making, composition writing and cloze test) on vocabulary learning and tried to compare the effectiveness of these assignments to see which one has the best effect. Accordingly, 102 homogeneous pre-intermediate EFL female learners, studying English at an institute in Shiraz, Iran, were randomly divided into three groups. At the beginning, an unannounced researcher-made pre-test including 60 multiple choice tests (60 vocabulary items, from all parts of speech) was administered which showed no learners knew all the items. Then during 6 sessions the 60 vocabulary items were taught (each session 10 items). Each session, in the first group the participants were asked to write a sentence for each of the 10 items. In the second group the participants were asked to write a composition using the 10 newly taught vocabulary, and in the third group the participants were asked to fill in the blanks of a cloze-test. After the $6^{\text {th }}$ session a post-test which was the same as the pre-test was administered. To analyze the data obtained from the tests, two one-way ANOVAs and three paired $t$-tests were utilized. The results indicated that all three assignments were significantly effective to help learners learn new vocabulary items and that the learners were not significantly different from each other in the pre-test. Moreover, the group which was to write a composition did significantly better in the post test than the two other groups but the difference between the two other groups was not significant. An interview was done by the researcher after the treatment period. The interview results confirmed the beneficial effects of these assignments on learners' vocabulary learning.
\end{abstract}

Keywords: Writing assignment, Cloze-test, Composition, Context, Second language learning strategy, Vocabulary learning

\section{Introduction}

Vocabulary as an important component of language plays an important part in learning a foreign or second language. There are different strategies to help learners acquire and consolidate new words. One of such strategies which is both easy and applicable in an EFL environment can be writing assignments.

According to Chastain (1988) writing is an important means of learning. Writing anything to be learned helps students practice the material and store it in a long term memory.

One principle of effective vocabulary learning is to provide multiple exposures to a word's meaning. There is great improvement in vocabulary when students encounter vocabulary words often (National Reading Panel, 2000). According to Stahl (2005), students probably have to see a word more than once to place it firmly in their long-term memories. This does not mean mere repetition or drill of the word, but seeing the word in different 
and multiple contexts. In other words, it is important that vocabulary instruction provide students with opportunities to encounter words repeatedly and in more than one context.

It can be said that testing vocabulary regularly can help learners to be more exposed to vocabulary. One way to test vocabulary is cloze test. Cloze tests require the ability to understand context and vocabulary in order to identify the correct words that belong to the deleted passages of a text. This exercise is commonly administered for the assessment of native and second language learning and instruction.

Some researchers (Harley, 1996; Yoshii, \& Flaitz, 2002) point to vocabulary learning as a vital part of each student's life, while other researchers though accept the importance of vocabulary acquisition in language proficiency and academic achievement, their ideas about how vocabulary should be learned have varied widely. Researchers in the field recognize the need for vocabulary acquisition especially at the intermediate level (Prince, 1996; Siribodhi, 1995). As language learning involves the acquisition of thousands of words, teachers and learners alike would like to know how vocabulary learning can be fostered, especially in EFL settings where learners frequently acquire impoverished lexicons, despite years of formal study. One of the major concerns is the need for developing effective pedagogical methods for the teaching of second language vocabulary. Traditional pedagogical methods for vocabulary acquisition include word-lists, dictionary use, workbooks, teacher-made materials, and group discussion. Yet developing effective pedagogical methods for vocabulary acquisition continues to demand attention and exploration.

In this connection, this study aims at finding out the effect of writing assignments and cloze test on vocabulary learning among Iranian EFL pre- intermediate EFLstudents.

\subsection{Objectives of the study}

Learning vocabulary is one of the first steps of learning a second language, yet a learner never finishes vocabulary acquisition. Whether in one's native language or a second language, the acquisition of new vocabulary is a continual process. Many methods can help one acquire new vocabulary.

This study was designed to investigate the influences that writing assignments of sentence making, composition writing and cloze test, have on vocabulary learning of Iranian pre- intermediate EFL students.

\subsection{Research questions}

In this study, answers to the following questions were sought:

1) Is there any relationship between sentence making and vocabulary learning?

2) Is there any relationship between writing composition and vocabulary learning?

3) Is there any relationship between cloze test and vocabulary learning?

4) Do learners learn vocabulary better through writing assignments of sentence making or those of writing compositions or even cloze-tests?

\section{Review of literature}

\subsection{Theoretical Concepts}

Hunt and Beglar (2005, p.2), argue that "the heart of language comprehension and use is the lexicon". Other authors have gone even further in arguing that "the single most important task facing language learners is acquiring a sufficient large vocabulary" (Lewis, 2000, p.8).

From the perspective of theory, a central focus of scholarly discussions and empirical investigations has been the very concept of vocabulary knowledge and lexical competence (Pavlenko, 1999; Nation, 2005), together with the related question of whether or not the unit of analysis/teaching should be the "word" (Gardner, 2007; Hunt \& Beglar, 2005), or the question about the dimensions of breadth and depth in lexical competence (Laufer \& Goldstein, 2004; Nation, 2005).

Learning vocabulary is an ongoing process that takes time and practice. Nakata (2006) acknowledged that vocabulary acquisition requires continual repetition in order for effective vocabulary learning. Vocabulary acquisition is not something a student can spend time learning or memorizing, like grammar, and be successful. Acquisition requires the learner to be disciplined, spending time each day working on words he/she does not know in order for learners to remember high frequency words and put them into their long term memory.

To help the students learn the important words from the context of a lesson a teacher needs to focus on low context words, which necessitate a second distinction: high frequency and low frequency words. Nation (2005) defined high frequency words as words that occur quite frequently in the language, such as the, a, man, and 
woman. Low frequency words, as described by Nation, are words that deal more with academic studies, words that appear throughout all academic texts and courses, but not very often in day to day speech, such as formulate, index, and modify.

Vocabulary, like other aspects of language learning, can be facilitated when done through cooperative learning. $\mathrm{Gu}(2003)$ pointed out that vocabulary acquisition is a very learner-centered activity with the effectiveness of the learner's strategies depending on his/her attitude and motivation towards new vocabulary acquisition (p. 2). This is true because the main motivational learning factor must come from the student, but when learning vocabulary in a cooperative learning environment it allows students to learn from peers closest to them. Murphey and Arao (2001) pointed out that students felt more relaxed and learned more from peers since they saw that making mistakes is acceptable, having goals is good, and learning English can be fun.

\subsection{The Importance of Vocabulary Learning Strategies}

In the past two decades, an increasing number of studies in the field of second language acquisition have addressed vocabulary learning (Kojic-Sabo \& Lightbown, 1999), including the effectiveness of various learning approaches.

It is often assumed that when students do not learn new vocabulary, they simply need to practice the words. Research has shown, however, that it is often the case that students simply do not understand the instructional task involved (National Reading Panel, 2000). The restructuring of learning materials or strategies in various ways often can lead to increased vocabulary acquisition, especially for low-achieving or at-risk students (National Reading Panel, 2000). According to Kamil (2004), once students know what is expected of them in a vocabulary task, they often learn rapidly.

Schmitt (2000) sees the need to help learners acquire the strategies necessary to learn words on their own. For Nation $(1990 ; 2001)$, the most important way to learn vocabulary is learners using strategies independently of a teacher. In his recent publication, strategy training is suggested to be part of a vocabulary development program. The main benefit gained from all learning strategies, including strategies for vocabulary learning, is the fact that they enable learners to take more control of their own learning so that students can take more responsibility for their studies (Nation, 2001; Scharle \& Szabo, 2000).

\subsection{Writing strategies to learn and teach vocabulary}

Writing in context, with attention to vocabulary use, is a tool for general second language improvement (Muncie, 2002). Maftoon (2006) states that teachers write key words on the board so that students have visual, as well as auditory, input. Since many students do not understand cursive writing, teachers need to print clearly and legibly. When students see written form of a word, they will learn it better, especially when they use these new words repeatedly in contexts, with the purpose of communication.

Panah Dehghani (2006-2007) concluded that there is a positive and direct relationship between written homework assignment and vocabulary learning among Iranian EFL beginners. The subjects of his study were divided randomly in two groups, a control and an experimental. During a two-month term the subjects were taught some new words, based on their books. The experimental group was asked to write two lines for each word as homework for the next class, while the control group only prepared the words orally. After finishing the book a vocabulary test was administered by the researcher. The result indicated that the experimental group outperformed the control group.

Writing and fill-in-the-blank activities are very common vocabulary tasks in ESL and EFL classrooms. Among the very few studies that have tackled these two tasks are those of Hulstijn and Laufer (2001) and Folse (2000). In Hulstijn and Laufer's study, the tasks investigated were: a) answering comprehension questions, b) filling-in-the-blanks of a passage and c) composition writing. The findings showed that writing was superior to the other two tasks in promoting learning and retention of the new words, while the task of answering comprehension questions was the least useful. In Folse's study, the tasks investigated were: a) one fill-in-the-blank exercise at the sentence level, b) three fill-in-the-blank exercises at the sentence level and c) writing original sentences. Folse found that students who did the three fill-in-the-blank exercises at the sentence level did significantly better than the other two groups and there was no significant difference between the other two conditions.

As we have seen, Hulstijn and Laufer (2001) compared the two types of activities at the text level, while in Folse (2000) the two activities were studied at the sentence level. Both studies produced different outcomes with regard to the effectiveness of the two types of treatments (writing and fill-in-the-blank). This discrepancy can perhaps be attributed to one of two factors. First, the two studies had different experimental designs. In addition, 
it could be that writing is more helpful at the text level than filling-in-the-blank, while at the sentence level, both tasks have an equal effect.

Another piece of research was done by Keshavarz and Estaji (2006) on the Iranian students. The main purpose of this study was to probe the possible impact of composition writing strategy instruction on the learning of newly taught words. They found out that composition writing had a great effect on learning second language vocabulary. The results suggest a wider application of composition writing strategies to promote meaningful learning.

Kargozari and Ghaemi (2011) in a study investigated the effectiveness of the type of written exercises on L2 vocabulary retention. To this end, 53 Iranian EFL university students practiced ten previously unencountered lexical items (the target words were all adjectives) in three types of written exercises: multiple choice exercise (MC), filling-in-the blank exercise (FW) and sentence writing exercise (SW). The participants were given a mini-dictionary designed to help them both for meaning and usage of the target words while doing the exercises. An unannounced posttest was administered and the data were analyzed by running a Kruskal-Wallis test. The findings revealed that the mean of MC exercise was significantly different from two other exercises, but no significant differences were found between FW and SW exercises.

At the end, in an answer to why writing is effective in improving vocabulary learning, Coomber et al. attributed this effectiveness to three factors (Coomber, Ramstad \& Sheets, 1986). The first factor is the use of the words in meaningful contexts. The second is the students' utilization of their higher level cognitive functions. The third factor has to do with the nature of the writing process in being slow which allows students to have more time to elaborate on the lexical items.

The Sentence Writing Method (also known as the Sentence Generate Method) is recommended by reading researchers as a way to increase vocabulary learning, and involves having learners construct a sentence containing the target word to be memorized (Dale, O’Rourke \& Bamman, 1971; Gipe, 1979 - cited in Pressley et al. 1982, p. 51).

So it can be reasonably concluded that writing in general generates more elaboration than merely matching words to context and such elaboration can be expected to result in better retention, as this research was also designed to detect more about the effects of three writing assignments, which are: sentence making, composition writing and cloze-test, on vocabulary learning of EFL students.

\section{Method}

\subsection{Participants}

The participants who took part in this experiment were 102 EFL students (all females) studying English at a language institute in Shiraz, Iran and their age ranged from 18 to 22. The students were native speakers of Persian. They were randomly divided into 3 groups by the researcher.

\subsection{Instruments}

Three instruments were utilized for data collection purposes in this study. They were:

1) A researcher-made multiple choice test with 60 items measuring the 60 newly taught vocabulary. It served as the pre-test and post-test in this study. In order to check the validity, the researcher consulted two experts (members of the thesis committee). After assuring its validity, the test was administered once and the data were put into SPSS (version 15). Cronbach's alpha was used to check the reliability. The result showed that the test was reliable $(\mathrm{r}=0.91)$;

2) Six cloze-tests, each containing a passage with 10 blanks and 10 newly taught vocabularies to fill in the blanks. (The passages were in accordance with the level of the students);

3) An interview done by the researcher with the participants.

\subsection{Procedure}

Three groups of instruction were formed and taught for 6 sessions. First of all The pre-test was administered to assure that the students did not already know the meanings of all the words to be taught to them in the treatment period and this helped the researcher to have a basis to check the learner's improvement. Then, 60 new vocabulary items from New Headway Series were taught using the communicative approach. 


\subsubsection{Procedure in the first group}

In the first group, $(\mathrm{N}=34)$, the students were taught 10 new vocabulary items each session and in the next session, they were asked to write sentences using the previously learnt vocabulary items. This continued until the $6^{\text {th }}$ session was over.

\subsubsection{Procedure in the second group}

In this group, which included 34 students, the students were taught 10 new vocabulary items each session and in the next session they were asked to write a composition using the previously learnt vocabulary items.

\subsubsection{Procedure in the third group}

An objective cloze test containing a passage with 10 blanks to be filled in with the 10 new vocabulary items which were taught was given a session after teaching the 10 new vocabulary items to the participants of this group which consisted of 32 students.

After completing the 6 sessions of instruction in all the groups, a post-test which was the same as the pre-test was administered to all the groups to check the rate of vocabulary learnt by the learners and to see which group did better.

All the above mentioned procedures were followed in the classroom and not at home or out of the class, because the researcher wanted to make sure that the students had done the assignments themselves, without any help from their parents or a dictionary, for example. The researcher chose the last 6 sessions of the term, because she had access to the participants during this period only. So the vocabulary items were also chosen from the three units of the book which were planned to be taught during the final 6 sessions based on the schedule prepared by the institute.

At last, the researcher had an interview with the participants to see whether they themselves believed that these three assignments helped them improve their vocabulary or not. This interview also served as a basis to support the statistical results, too. To this end, the participants in each group answered the following questions on a piece of paper.

\subsection{Data analysis}

After collecting the data, the SPSS 15 package was used. Because the study contained one independent variable with three levels (i.e. sentence making, composition writing and cloze test) and one dependent variable (i.e. vocabulary learning) and since three groups were used 2 one-way ANOVAs were conducted, one on pre-test scores of the learners and another on post-test scores to see which of the mentioned strategies had the best effect on vocabulary learning of pre-intermediate EFL students.

The researcher also made use of matched $t$-test (paired $t$-test), because for each student in each group there were two scores and the researcher wanted to see whether the treatments in each group had an effect on the students of that group or not.

\section{Results and Discussion}

\subsection{Results}

First, considering the levels of the groups, there was a probability that before the treatments were done the students of one group were better than the students of the other two groups. So, the researcher made use of a one way ANOVA on the pre-test scores of the participants as presented in Table 1.

\subsubsection{Matched t-test}

In this study, each student in each group had two scores (one for pre-test and another one for post-test). To see if the treatments in each group had an effect on the students of that group, a matched $t$-test for each group was run separately as shown in separate tables (Tables $3,4 \& 5$ ) followed by brief interpretations.

\subsubsection{One way ANOVA}

In this research, a researcher-made multiple choice test served as a pre-test and post test. In order to analyze the data obtained from the pre-test and post-test, the SPSS package version 15 was used. Because the study contained one dependent variable (i.e. vocabulary learning) and one independent variable with three levels (i.e. sentence making, composition writing \& cloze test) a one-way ANOVA was appropriate to show the effect of those three assignments on learners' vocabulary learning. The results of the one-way ANOVA are shown in Table 6. 


\subsubsection{Interview results}

To support the statistical results of the study, the researcher conducted an interview with the participants of each group. The following tables and pie graphs show the degree of agreement or disagreement of the participants with the effectiveness of the assignments in each group.

\subsubsection{Results of sentence making group}

The point raised in the first group was:

- Making sentences using newly taught words helped me learn them better.

$$
\text { 1.strongly agree 2.agree } 3 \text {.undecided } \quad 4 \text {.disagree } 5 \text {.strongly disagree }
$$

The degree of agreement or disagreement of the participants of this group to the effectiveness of this assignment is shown in Table 8.

\subsubsection{Results of composition writing group}

The point raised in the second group was:

- Writing composition using newly taught words helped me learn them better

$$
\text { 1.strongly agree 2.agree } 3 \text {.undecided } \quad \text { 4.disagree } 5 . \text { strongly disagree }
$$

The degree of agreement or disagreement of the participants of this group to the effectiveness of this assignment is shown in Table 9.

\subsubsection{Results of cloze-test group}

The point raised in the third group was:

- Completing a cloze-test using newly taught words helped me learn them better

$$
\text { 1.strongly agree } \quad \text { 2.agree } \quad 3 \text {.undecided } \quad \text { 4.disagree } \quad 5 \text {.strongly disagree }
$$

The degree of agreement or disagreement of the participants of this group to the effectiveness of this assignment is shown in Table 10.

\subsection{Discussion}

The analysis of data in this study revealed that the composition writing group (Table 7) significantly outperformed the two other groups, because the differences between composition writing group and the two other groups were significant. So, it shows that application of composition writing assignment promotes vocabulary learning the best. This is also in line with the findings of Keshavarz, and Estaji's (2006) research on the Iranian students whose main purpose was to probe the possible impact of composition writing strategy instruction on the learning of newly taught words in that they also found out that composition writing had a great effect on learning second language vocabulary. And the results of their study suggest a wider application of composition writing strategies to promote meaningful learning.

Although cloze test has a positive effect on vocabulary learning based on the findings of the paired $t$-test results, the researchers can't support this finding by any research previously conducted because of the shortage of studies on effect of cloze test on vocabulary learning of EFL learners.

However, If we consider cloze test similar to SF (filling-in-the-blank of a sentence) in Hulstijn's (2001) and (filling-in-the-blank of a passage) in Hulstijn and Laufer's (2001) studies, although they found a significant difference between SF and SW (sentence writing) exercises, the findings of the current study did not support them. Because in the current study the difference between these two groups was not significant $(p>0.05)$. However, the findings of the current study confirm the findings of Hulstijn and Laufer's study in that writing was superior to the other two tasks in promoting vocabulary learning.

In Hulstijn and Laufer's study, the tasks investigated were: a) answering comprehension questions, b) filling-in-the-blank of a passage and c) composition writing. The findings showed that writing was superior to the other two tasks in promoting learning and retention of the new words, while the task of answering comprehension questions was the least useful.

In cloze test group, the students are involved both semantically and syntactically. Due to matching nature of this assignment, students either compare the target words to select the appropriate ones for the blank in question or they process the context in which the blanks are to find syntactic or semantic clues for selecting the target words. During the processing of the context, the students will have the target words in their minds and will think about 
the most appropriate choice to complete the blanks. Of course, students focus mostly on meaning not on grammar.

The analysis of data from a paired $t$-test revealed that the sentence making has a positive effect on vocabulary learning, a finding which is to some extent in contrast to some research to determine the effectiveness of sentence writing as a vocabulary memorization strategy and also in line with other research: While three studies have found that sentence writing did not facilitate either the production or the recall of definitions of words learnt under this technique (Barcroft, 2000, Nielsen, 2001), the findings of some other studies suggest that sentence writing is an effective method for facilitating memorization of words (Coomber, Ramstad,\& Sheets, 1986; Laufer, 1997).

The findings of this research also lent support to Muncie's (2002) claim that writing in context with attention to vocabulary use is a tool for improving second language in general.

The findings of the present study are supported by Chastain (1988) who believes that writing is an important means of learning. Writing anything to be learned helps students practice the material and store it in a long term memory. The appropriateness of the writing assignments as employed in this study, is also recommended by (Swain \& Lapkin, 1995 who maintain that presenting both types of writing (sentence \& composition) pushes the students to use the language in original and meaningful contexts (i.e., this is normally referred to as 'pushed output') as mentioned by Swain and Lapkin (1995). Pushed output, in addition to improving learner's grammar, has been found to improve vocabulary learning and retention (Swain, 1995).

From the above discussion, we can infer that there are three factors attributing to the effectiveness of writing in improving vocabulary learning (Coomber, Ramstad \& Sheets, 1986). The first factor is the use of the words in meaningful contexts. The second is the students' utilization of their higher level cognitive functions. The third factor has to do with the nature of the writing process in being slow which allows students to have more time to elaborate on the lexical items. All the three groups are engaged with these three factors but its depth is deeper and more mental processes are used in composition writing group than the two other ones. So, the learners using this assignment to improve vocabulary learning are more successful in learning new words.

\section{Conclusion}

Since a good knowledge of vocabulary has a great effect on the learners' improvement of other aspects of language such as reading comprehension, listening comprehension, speaking, and writing due attention should be paid to choosing and implementing appropriate vocabulary teaching/learning techniques in language classes.

This study was an investigation of effects of the use of writing assignments in an English class to improve students' English vocabulary learning. The findings of the study support the idea that the use of writing assignments improves vocabulary acquisition. In particular, the results lead one to conclude that of the three writing assignments the most effective way to improve the learning of English vocabulary is composition writing. Now to have a more detailed conclusion the research questions will be answered:

1) Is there any relationship between sentence making and vocabulary learning?

To answer this research question we refer to the paired $t$-test for sentence making group and since the significance level was 0.000 which was less than .05 , it can be said that the treatment (i.e. sentence making) was effective and there is a positive relationship between sentence making and vocabulary learning.

2) Is there any relationship between writing composition and vocabulary learning?

According to the paired $t$-test for composition writing group and the significance level of 0.000 which was less than .05 , it can be concluded that this treatment (i.e. composition writing) was also effective and there is a positive relationship between composition writing and vocabulary learning.

3) Is there any relationship between cloze test and vocabulary learning?

Based on the paired $t$-test for cloze-test group, the answer to this question is yes, because the significance is 0.000 which is less than .05 .

4) Do learners learn vocabulary better through writing assignments of writing composition or that of a sentence making or even a cloze test?

Results of the one way ANOVA on data obtained from the post test scores of students in all groups showed no differences between the sentence making and cloze test groups at the .05 level of significance. Although the mean score obtained from the post-test scores of cloze-test was more than that of sentence making group (Tables 3 and 5), the difference is not significant. But there is a significant difference between composition writing group 
compared to the other two groups. This result leads one to conclude that learners learn vocabulary better through writing composition than through sentence making or even cloze test.

\section{References}

Barcroft, J. (2000). The effects of sentence writing as semantic elaboration on the allocation of processing resources and second language lexical acquisition $\mathrm{PhD}$ diss., University of Illinois at Urbana-Champaign.

Chastain, K. (1988). Developing second language skills: Theory and practice. University of Virginia.

Coomber, J., D. Ramstad \& D. Sheets. (1986). Elaboration in vocabulary learning: A comparison of three rehearsal methods. Research in the Teaching of English, 20(3), 281-293.

Folse, K. (2000). The effect of type of written practice activity on second language vocabulary retention. Unpublished doctoral dissertation, University of South Florida.

Gardner, D. (2007). Validating the construct of word in applied corpus-based vocabulary research: A critical survey. Applied Linguistics, 28(2), 241-265. http://dx.doi.org/10.1093/applin/amm010

$\mathrm{Gu}, \mathrm{Y}$. (2003). Fine brush and freehand: The vocabulary learning art of two successful Chinese EFL learners. TESOL Quarterly, 37, 73-104. http://dx.doi.org/10.2307/3588466

Harley, B. (1996). Introduction: Vocabulary learning and teaching in a second language. The Canadian Modern Language Review, 53(1), 3-11.

Hulstijn, J. \& B. Laufer, (2001). Some empirical evidence for the involvement load hypothesis in vocabulary acquisition. Language Learning, 51(3), 539-558. http://dx.doi.org/10.1111/0023-8333.00164

Hunt, A. \& Beglar, D. (2005). A framework for developing EFL reading vocabulary. Reading in a Foreign Language, 17, 23-59.

Kamil, M.L. (2004). Vocabulary and comprehension instruction: Summary and implications of the National Reading Panel finding. In P. McCardle and V. Chhabra (eds.), The voice of evidence in reading and research. Baltimore, MD: Paul H. Brookes.

Kargozari, H. R. \& Ghaemi, H. (2011). A reappraisal perspective on written tasks types and vocabulary acquisition and retention of EFL learners. World Applied Sciences Journal, 12(10), 1653-1661.

Keshavarz, M.H. \& Estagi, M. (2006). The impact of writing strategies instruction on Iranian students' learning of newly taught words. Roshed FLT, Vol. 21, pp. 50-58, Ministry of Education, Iran.

Kojic-Sabo, I. \& Lightbown, P. (1999). Students' approaches to vocabulary learning and their relationship to success. The Modern Language Journal, 83(2), 176-192. http://dx.doi.org/10.1111/0026-7902.00014

Laufer, B. \& Goldstein, Z. (2004). Testing vocabulary knowledge: Size, strength, and computer adaptiveness. Language Learning, 54(3), 399-436. http://dx.doi.org/10.1111/j.0023-8333.2004.00260.x

Laufer, B. (1997). The lexical plight in second language reading: Words you don't know, words you think you know, and words you can't guess. In J. Coady \& T. Huckin (Eds.), Second language vocabulary acquisition (pp. 20-34). New York: Cambridge University Press.

Lewis, M. (2000). Introduction. In M. Lewis (Ed.), Teaching collocation. Further developments in the lexical approach. Hove: Language Teaching publications, pp. 8-9.

Maftoon, P. (2006). Key to effective communication. Roshd FLT, Foreign Language Teaching Journal, Vol. 20, p. 58. Ministry of education, Iran.

Muncie, J. (2002). Process writing and vocabulary development: comparing lexical frequency profiles across drafts. System, 30, 225-235. http://dx.doi.org/10.1016/S0346-251X(02)00006-4

Murphey, T. \& Arao, H. (2001). Reported belief changes through near peer role modeling. TESL-EJ, 5(3). [Online] Available: http://www- writing.berkeley.edu/TESL- EJ/ej19/a1.html (June 1, 2006)

Nakata, T. (2006). Implementing optimal spaced learning for English vocabulary learning: Towards improvement of the low-first method derived from the re- activation theory. The JALT CALL Journal, 2(2), 3-18.

Nation, I. S. P. (2001). Learning vocabulary in another language. New York: Cambridge University Press.

Nation, P. (1990). Teaching and Learning Vocabulary. New York: Newbury House Publishers.

Nation, P. (2005). Range and frequency instructions [Computer software]. [Online] Available: http://www.vuw.ac.nz/lals/staff/paul -nation/nation.aspx (March 3, 2006) 
Nation, P. (2005). Teaching vocabulary. Asian EFL Journal, 7(3), 47-54.

National Reading Panel. (2000). Teaching children to read: An evidence-based assessment of the scientific research literature on reading and its implications for reading instruction. Washington, DC: National Institute of Child Health and Human Development.

Nielsen, B. M. (2001). The effectiveness of sentence generation on the acquisition of receptive and productive knowledge of explicitly presented lexical items. Unpublished M.Ed. thesis, University of Wollongong, NSW Australia.

Panah Dehghani, A. (2006-2007). The effect of homework assignment on learning vocabulary among Iranian EFL beginners. Unpublished M.A. thesis, Islamic Azad university, Shiraz, Iran.

Pavlenko, A. (1999). New approaches to concepts in bilingual memory. Bilingualism: Language and Cognition, 2, 209-230. http://dx.doi.org/10.1017/S1366728999000322

Pressley, M., Levin, J.R. \& Miller, G.E. (1982). The keyword method compared to alternative vocabulary-learning strategies. Contemporary Educational Psychology, 7, 50-60. http://dx.doi.org/10.1016/0361-476X(82)90007-8

Prince, P. (1996). Second Language vocabulary learning: The role of context versus translations as a function of proficiency. The Modern Language Journal, 80, 478-493. http://dx.doi.org/10.1111/j.1540-4781.1996.tb05468.x

Scharle, Á. \& Szabó, A. (2000). Learner autonomy: A guide to developing learner responsibility. Cambridge: Cambridge University Press.

Schmitt, N. (2000). Vocabulary in language teaching. Cambridge: Cambridge University Press.

Siribodhi, T. (1995). Effects of three interactive multimedia computer assisted language learning programs on the vocabulary acquisition of elementary level EFL students. Unpublished doctoral dissertation, The University of Kansas.

Stahl, S.A. (2005). Four problems with teaching word meanings (and what to do to make vocabulary an integral part of instruction). In E.H. Hiebert and M.L. Kamil (eds.), Teaching and learning vocabulary: Bringing research to practice. Mahwah, NJ: Erlbaum.

Swain, M. \& S. Lapkin. (1995). Problems in output and the cognitive processes they generate: A step towards second language learning. Applied Linguistics, 16 (3): 371-391.

Swain, M. (1995). Three functions of output in second language learning. In G. Cook and B. Seidelhofer, (Eds.), Principle and practice in applied Linguistics (pp: 125-144). Oxford: Oxford University Press. http://dx.doi.org/10.1093/applin/16.3.371

Yoshii, M. \& Flaitz, J. (2002). Second language incidental vocabulary retention: the effect of text and picture annotation types. CALICO Journal, 20(1), 33-58.

Table 1. ANOVA results on the pre-test

\begin{tabular}{|c|c|c|c|c|c|}
\hline \multicolumn{6}{|c|}{ ANOVA } \\
\hline & $\begin{array}{l}\text { Sum of } \\
\text { Squares }\end{array}$ & df & Mean Square & $\mathrm{F}$ & Sig. \\
\hline $\begin{array}{l}\text { Between Groups } \\
\text { Within Groups } \\
\text { Total }\end{array}$ & $\begin{array}{r}402.412 \\
10870.265 \\
11272.676\end{array}$ & $\begin{array}{r}2 \\
99 \\
101\end{array}$ & $\begin{array}{l}201.206 \\
109.801\end{array}$ & 1.832 & .165 \\
\hline
\end{tabular}

The table shows that there are no significant differences between the groups, because the significance is 0.165 which is more than $0.05(\mathrm{p}>0.05)$. If we take a look at the posthoc table,too (Table 2) we can see that there is no asterisk added by the computer in the post hoc table, since the difference between the means is not significant. 
Table 2. Post Hoc Tests on post test scores

\section{Multiple Comparisons}

Dependent Variable: scores

\begin{tabular}{|c|c|c|c|c|c|c|c|}
\hline & \multirow[b]{2}{*}{ (I) groups } & \multirow[b]{2}{*}{ (J) groups } & \multirow{2}{*}{$\begin{array}{c}\text { Mean } \\
\text { Difference } \\
(\mathrm{I}-\mathrm{J})\end{array}$} & \multirow[b]{2}{*}{ Std. Error } & \multirow[b]{2}{*}{ Sig. } & \multicolumn{2}{|c|}{$95 \%$ Confidence Interval } \\
\hline & & & & & & Lower Bound & Upper Bound \\
\hline \multirow[t]{6}{*}{ Scheffe } & \multirow[t]{2}{*}{ composition writing } & \multirow{2}{*}{$\begin{array}{l}\text { cloze test } \\
\text { sentence making }\end{array}$} & 4.44118 & 2.54143 & .222 & -1.8749 & 10.7573 \\
\hline & & & 3.94118 & 2.54143 & .305 & -2.3749 & 10.2573 \\
\hline & \multirow[t]{2}{*}{ cloze test } & \multirow{2}{*}{$\begin{array}{l}\text { composition writing } \\
\text { sentence making }\end{array}$} & -4.44118 & 2.54143 & .222 & -10.7573 & 1.8749 \\
\hline & & & -.50000 & 2.54143 & .981 & -6.8161 & 5.8161 \\
\hline & \multirow[t]{2}{*}{ sentence making } & \multirow{2}{*}{$\begin{array}{l}\text { composition writing } \\
\text { cloze test }\end{array}$} & -3.94118 & 2.54143 & .305 & -10.2573 & 2.3749 \\
\hline & & & .50000 & 2.54143 & .981 & -5.8161 & 6.8161 \\
\hline
\end{tabular}

So, it can be said that the groups are not different in pretest scores and we had homogeneous participants.

\section{Matched t-test for sentence making group}

Table 3. Paired samples t-test

Paired Samples Test

\begin{tabular}{|c|c|c|c|c|c|c|c|c|c|}
\hline & & & & Difference & & & & & \\
\hline & & & & Std. Error & $\begin{array}{r}95 \% \text { C } \\
\text { Interv } \\
\text { Diffe }\end{array}$ & $\begin{array}{l}\text { idence } \\
\text { of the } \\
\text { nce }\end{array}$ & & & \\
\hline & & Mean & Std. Deviation & Mean & Lower & Upper & $t$ & df & Sig. (2-tailed) \\
\hline Pair 1 & prescores - postscores & -13.76471 & 6.51831 & 1.11788 & -16.03905 & -11.49036 & -12.313 & 33 & .000 \\
\hline
\end{tabular}

Table 3 gives the results of the $t$-test. The significance given by the computer is .000 which is smaller than .05 . Therefore, the treatment (sentence making) has had a positive effect on the students' vocabulary learning.

\section{Matched t-test for composition writing group}

Table 4. Paired samples t-test

Paired Samples Test

\begin{tabular}{|c|c|c|c|c|c|c|c|c|c|}
\hline & & \multicolumn{5}{|c|}{ Paired Differences } & \multirow[b]{3}{*}{$\mathrm{t}$} & \multirow[b]{3}{*}{ df } & \multirow[b]{3}{*}{ Sig. (2-tailed) } \\
\hline & & \multirow[b]{2}{*}{ Mean } & \multirow[b]{2}{*}{ Std. Deviation } & \multirow{2}{*}{$\begin{array}{l}\text { Std. Error } \\
\text { Mean }\end{array}$} & \multicolumn{2}{|c|}{$\begin{array}{l}\text { 95\% Confidence } \\
\text { Interval of the } \\
\text { Difference }\end{array}$} & & & \\
\hline & & & & & Lower & Upper & & & \\
\hline Pair 1 & prescores - postscores & -17.94118 & 5.31972 & .91233 & -19.79732 & -16.08504 & -19.665 & 33 & .000 \\
\hline
\end{tabular}

Table 4 gives the results of the $t$-test. The significance given by the computer is .000 in this group which is smaller than .05. Therefore, the treatment has had a positive effect on the students of composition writing group.

\section{Matched $t$-test for cloze test group}

Table 5. Paired samples t-test

Paired Samples Test

\begin{tabular}{|c|c|c|c|c|c|c|c|c|c|}
\hline & & \multicolumn{5}{|c|}{ Paired Differences } & \multirow[b]{3}{*}{$\mathrm{t}$} & \multirow[b]{3}{*}{$\mathrm{df}$} & \multirow[b]{3}{*}{ Sig. (2-tailed) } \\
\hline & & \multirow[b]{2}{*}{ Mean } & \multirow[b]{2}{*}{ Std. Deviation } & \multirow{2}{*}{$\begin{array}{c}\text { Std. Error } \\
\text { Mean }\end{array}$} & \multicolumn{2}{|c|}{$\begin{array}{l}95 \% \text { Confidence } \\
\text { Interval of the } \\
\text { Difference }\end{array}$} & & & \\
\hline & & & & & Lower & Upper & & & \\
\hline Pair 1 & prescores - postscores & -14.64706 & 6.97998 & 1.19706 & -17.08249 & -12.21163 & -12.236 & 33 & .000 \\
\hline
\end{tabular}

For the third group, Table 5 gives the results of the $t$-test. The significance given by the computer is again .000 which is smaller than .05. In other words, the treatment has had a positive effect on the students of cloze-test group. 
Table 6. ANOVA results on post test

\begin{tabular}{|c|c|c|c|c|c|}
\hline \multicolumn{6}{|c|}{ ANOVA } \\
\hline & $\begin{array}{l}\text { Sum of } \\
\text { Squares }\end{array}$ & df & Mean Square & $\mathrm{F}$ & Sig. \\
\hline Between Groups & 1421.725 & 2 & 710.863 & 5.365 & .006 \\
\hline Within Groups & 13116.941 & 99 & 132.494 & & \\
\hline Total & 14538.667 & 101 & & & \\
\hline
\end{tabular}

As the above table shows, the significance is 0.006 which is smaller than .05 , so the differences between the groups are significant. It is clear that the students in each group differ in English vocabulary learning, but it is not clear exactly which two groups are different from each other. This can be made clear through the post hoc table (Table 7).

Table 7. Post Hoc Tests on post test scores

Multiple Comparisons

Dependent Variable: scores

\begin{tabular}{|c|c|c|c|c|c|c|c|}
\hline & \multirow[b]{2}{*}{ (I) groups } & \multirow[b]{2}{*}{ (J) groups } & \multirow{2}{*}{$\begin{array}{c}\text { Mean } \\
\text { Difference } \\
(I-J)\end{array}$} & \multirow[b]{2}{*}{ Std. Error } & \multirow[b]{2}{*}{ Sig. } & \multicolumn{2}{|c|}{ 95\% Confidence Interval } \\
\hline & & & & & & Lower Bound & Upper Bound \\
\hline \multirow[t]{6}{*}{ Scheffe } & \multirow[t]{2}{*}{ composition writing } & cloze test & $7.70588^{\star}$ & 2.79174 & .025 & .7677 & 14.6440 \\
\hline & & sentence making & $8.11765^{*}$ & 2.79174 & .017 & 1.1795 & 15.0558 \\
\hline & \multirow[t]{2}{*}{ cloze test } & composition writing & $-7.70588^{*}$ & 2.79174 & .025 & -14.6440 & -.7677 \\
\hline & & sentence making & .41176 & 2.79174 & .989 & -6.5264 & 7.3499 \\
\hline & \multirow[t]{2}{*}{ sentence making } & composition writing & $-8.11765^{*}$ & 2.79174 & .017 & -15.0558 & -1.1795 \\
\hline & & cloze test & -.41176 & 2.79174 & .989 & -7.3499 & 6.5264 \\
\hline
\end{tabular}

*. The mean difference is significant at the .05 level.

In post hoc analysis on post test scores (Table 7) the groups are compared two by two and the results are given. Where the difference between means is significant, the computer adds an asterisk. Moreover, the significance level is provided and we can decide to reject or retain the null hypothesis. It is seen from the above table that the difference between composition writing and sentence making is significant $(p=0.017<0.05)$. The mean differences are negative, so we can conclude that the mean in composition writing Group was greater than the mean in sentence making Group. So, the students in composition writing group learned better.

$$
\mathrm{x} \text { sentence making } \_\mathrm{x} \text { composition writing }=\_8.117
$$

The difference between composition writing and cloze-test is also significant $(p=0.025<0.05)$. The mean differences are negative, so it can be concluded that the mean in composition writing Group was greater than the mean in cloze-test Group.

$$
\mathrm{x} \text { cloze-test } \_\mathrm{x} \text { composition writing }=\_7.705
$$

So, the students in composition writing group learned better than the students in cloze-test group. No other comparisons are statistically significant. Composition writing students differ from all other students, but no statistically significant difference can be found in the other comparison: cloze-test / sentence making. The students in cloze-test group do not significantly differ from the students of sentence making group, as the difference is not significant. The two groups have almost equally improved. 
Table 8. The percentage of the participants' agreement/disagreement in the sentence making group

\begin{tabular}{|l|l|}
\hline Degree of agreement & Percent \\
\hline strongly agree & $\mathbf{4 0}$ \\
\hline agree & $\mathbf{4 7}$ \\
\hline undecided & $\mathbf{3}$ \\
\hline disagree & $\mathbf{8}$ \\
\hline strongly disagree & $\mathbf{2}$ \\
\hline
\end{tabular}

As it can be seen from the above table $87 \%$ of the respondents agreed (47\%) or strongly agreed $(40 \%)$ that the sentence making assignment helped them improve their vocabulary learning. So, most of them believed that it was an effective assignment, a result which supports the matched $t$-test analysis, too.

Table 9. The percentage of the participants' agreement/disagreement in the composition writing group

\begin{tabular}{|c|c|}
\hline Degree of agreement & Percent \\
\hline strongly agree & 38 \\
\hline agree & 44 \\
\hline undecided & 5 \\
\hline disagree & 8 \\
\hline strongly disagree & 5 \\
\hline
\end{tabular}

Table 9 shows that $82 \%$ of the respondents agreed (44\%) or strongly agreed (38\%) that the composition writing assignment helped them improve their vocabulary learning. So, the majority of the participants believed that it was an effective assignment, a result which supports the matched $t$-test analysis of this assignment.

Table 10. The percentage of the participants' agreement/disagreement in the cloze-test group

\begin{tabular}{|l|l|}
\hline Degree of agreement & Percent \\
\hline strongly agree & $\mathbf{3 0}$ \\
\hline agree & $\mathbf{4 7}$ \\
\hline undecided & $\mathbf{2}$ \\
\hline disagree & $\mathbf{1 2}$ \\
\hline strongly disagree & $\mathbf{9}$ \\
\hline
\end{tabular}

As Table 10 shows $77 \%$ of the respondents agreed (47\%) or strongly agreed (30\%) that the cloze-test helped them improve their vocabulary learning. It is clear that the majority of the participants in this group also believed that it was an effective assignment, a result which supports the matched $t$-test analysis of this group. 